\title{
Virologic Response
}

National Cancer Institute

\section{Source}

National Cancer Institute. Virologic Response. NCI Thesaurus. Code C120544.

A description of the change in viral disease status in response to treatment. 